\title{
Direct and Indirect Directive Illocutionary Acts in the Movie "Penguin of Madagascar"
}

\author{
Gusti Alit Mahendra \\ English Department, Faculty of Arts, Udayana University \\ [alit.mahendra1@gmail.com]
}

\begin{abstract}
Abstrak
Penelitian yang berjudul "Direct and Indirect Directive Illocutionary Acts in the Movie Penguin of Madagascar" bertujuan untuk menganalisis ujaran langsung dan tidak langsung dalam suatu kalimat perintah dan menjelaskan serta menganalisis arti ujaran tersebut dari interpretasi pendengar. Data dalam penelitian ini diambil dari film yang berjudul Penguin of Madagascar. Film ini dipilih karena banyak ujaran-ujaran diidentifikasi sebagai tindak tutur direktif dari tindakan ilokusi. Metode observasi digunakan dalam mengumpulkan data dikarenakan data yang diperoleh bersumber dari ujaran, seperti yang terdapat dalam film. Data dianalisis dengan menggunakan metode deskriptif kualitatif karena tujuan penelitian ini adalah untuk menganalisis fenomena sosial seperti tindak tutur.Teori Bach dan Harnish (1979: 47) digunakan untuk menganalisis jenis tindak tutur direktif dalam tindak ilokusi. Teori tentang, konteks situasi diusulkan oleh Hymes (1972) digunakan untuk menganalisis makna tindak tutur direktif dalam tindak ilokusi yang dapat diinterpretasikan oleh pendengar.Bach and Harnish (1974) menyatakan bahwa ada enam jenis tindak tutur direktif yaitu: permintaan, pertanyaan, persyaratan, permisif, larangan dan nasihat. Dalam penelitian ini, beberapa jenis direktif ilokusi yang ditemukan dalam film, kecuali ujaran pertanyaan tidak langsung, dan ujaran larangan langsung. Cara pendengar menafsirkan makna tergantung pada konteks situasi.
\end{abstract}

Kata kunci: tindak tutur, tipe ujaran direktif, etnografi komunikasi

\begin{abstract}
The study entitled "Direct and Indirect Directive Illocutionary Acts in the Movie Penguin of Madagascar" is aimed at identifying the direct and indirect directive types of illocutionary acts and explaining and analyzing the meaning of the utterances interpreted by the listeners. The data of this study were taken from the movie entitled Penguins of Madagascar, and it was chosen because of many utterances identified as directive of illocutionary acts. The observation and documentation methods were used in collecting the data since the data were obtained from the spoken source in the movie. The data were analyzed using the descriptive qualitative method since the purpose of this study is to analyze the social phenomena like speech acts. The first theory proposef by Bach and Harnish (1979: 47) is used to analyze the type of directive of illocutionary acts. The second theory, the context of situation proposed by Dell Hymes (1972, is used to analyze the meaning of directive of illocutionary acts that can be interpreted by the listeners. There are six types of directive of illocutionary act proposed by Bach and Harnish (1979). They are requestives, questions, requirements, permissives, prohibitives and advisories. In this study, several types of directive illocutionary were
\end{abstract}


found in the movie, except the indirect question, and direct prohibitive. The way the listeners interpret the meaning depends on the context of situation.

Key word: Speech Acts Types, Directive Illocutionary Acts.

\section{Background}

In communication there are cases where the speaker tends to mean more than what he actually says literally. In contrast, it is possible what the speaker says is different from what he intends that the hearer may recognize the massage or force intend beyond what the speaker says literally. The act that a speaker performs when making an utterance is called 'speech act' (Austin 1962)

Speech act is the act of making an utterance in which the speaker is performing certain kinds of act, such as: making an offer, asking question, apologizing, making promise, describing something, etc. Austin identifies three distinct levels of action beyond the act of utterance itself, the first is locutionary act, illocutionary act and perlocutionary act. The illlocutionary act is the one that is quite complex, form an utterance with some functions in the mind performed via the communicative force of an utterance. When the speaker utters something, the real meaning often confuses the hearers because the speaker sometimes utters it in indirect way. Illocutionary act is divided into five categories: representative, directive, commisive, expressive, and declaration. Directive of illocutionary act is chosen as the focus of the discussion in order to make the study more relevant. The point of the directive illocutionary act is request to do something stated by the speaker such as requesting, asking, ordering, commanding, begging, etc. That is the reason why people have to interpret the meaning of language through speech act. Many times people are not only saying but also forcing the hearer to do something. When the hearer is doing an act, it means that he or she is doing illocutionaryact.

In connection with indirect speech acts, Searle (1970:30) introduces the notions of 'primary' and 'secondary 'illocutionary acts. The primary one is the indirect one, which is not literally performed. The secondary illocutionary act is the direct one, performed in literal utterance. This study focuses on the 'primary' and 'secondary' or indirect and direct directive illocutionary acts used in the movie Penguin of Madagascar.

Movie is a recording of moving images that tells a story and that people watch on a screen or television, reflects the human social life. Movie is also often called film; the most important form is the dialog (conversation) among the characters. Characters communicate with each other and will raise Illocutionary act.

The data were obtained from the movie Penguin of Madagascar. The movie is animation, adventurous comedy, and military context where one of them is the leader. In speech act the utterance does not only always mean literal, but it may mean something else. Therefore, this topic is chosen because of the complexity of the meaning.

\section{Problems of the Study}

a) What types of directive of illocutionary acts were found in the movie Penguin of Madagascar?

b) What are the meanings of the utterances interpreted by the hearers?

\section{Aims of the Study}


a) To identify the types of directive illocutionary act used in the movie.

b) To explain and analyze what the meaning of directive utterance of illocutionary act are interpreted by the hearers.

\section{Research Method}

In conducting research, an appropriate methodology plays a very significant role. There are four points to be discussed in this section. The research method, method and technique of collecting data, method and technique of analyzing data, and method and technique of presenting data.

\subsection{Data source}

The data source of this study were taken from animation movie entitled "Penguin of Madagascar". The movie is a 2014 animation, adventure, comedy movie, which was produced by Dream Works and directed by Eric Darnell and Simon J.Smith. It was published in the USA on November 26, 2014. This film was chosen because it has a large number of utterances indicating command, which is what this study focuses on.

\subsection{Method and technique of collecting data}

The method used in collecting the data was observation and documentation since the data were obtained from the spoken source. The data were taken from a movie entitled "Penguin of Madagascar" since all types of directive of illocutionary acts could be obtained from this

film.

There are several steps done in collecting the data. First, the movie was downloaded from the internet. Second, the dialogues in the movie were noted to which utterance is categorized as directive illocutionary act. Third, the related data were classified into the types of illocutionary act.

\subsection{Method and Technique of Analyzing Data.}

The descriptive qualitative is the method used in this study. The qualitative method is the way of analyzing data in which there are several theories applied in the study and there is no calculation on statistic data involved. This study used the qualitative method combined with the descriptive method.

There are several steps of analyzing data. First, the direct and indirect types of directive illocutionary act were identified. Second, the data found were grouped into their categorizations based on the types of directive illocutionary act using the theory proposed by Bach and Harnish (1979). Then finally, the meaning of the utterances that can be interpreted by the hearer was identified using the theory of context of situation (S-P-E-A-K-I-N-G model) proposed by Dell Hymes (1972).

\subsection{Method and Technique of Presenting Data}

In conducting this study, the qualitative and descriptive methods were used to present the data since there were several theories used in this study. Later, the data were presented descriptively in order to get a better understanding.

The analysis was presented by firstly showing the data in the form of sentences. The utterances were typed in bold; therefore, the readers can understand the directive illocutionary acts easily. The analysis of the types of directive illocutionary act and the interpretation of meaning were explained further descriptively by applying the theories of communicative illocutionary act proposed by Bach and Harnish (1979) and the context of situation proposed by Dell Hymes (1972). 


\section{Result and discussion \\ 5.1 Direct of Directive Illocutionary Acts}

In this analysis, there are five conversations considered as the direct of directive illocutionary act found in the movie.

\subsubsection{Requestives}

"I want to help the team. Really help the team! If you think I'm ready, which I'am! Assuming you agree, and perhaps even... if you don't"

The first data is a direct speech act. The reason is that the speaker says what he literally means or what he exactly says. The first data is also classified as directive of requestives since the speaker is performing an expression of begging to Skipper by saying the utterance. This conversation occurs in the middle of the movie, when the penguins want to trap Dave, the octopus. Private is the youngest, cutest and the most loved by the members of the team, therefore Skipper will not give him a heavy order that will risk him. However, Private fells that he himself is ready for a bigger challenge than only being a diversion. Unfortunately, Skipper does not change his decision and still wants Private to be the diversion of penguin which looks like a mermaid in the zoo at Shanghai. However, Skipper's plan didn't go to plan. At first, the penguins are successful in trapping Dave with a falling fish fossil. Immediately, Dave, the octopus, frees himself into the pipe channel, and sneaks into the mermaid penguin's pool tank. Immediately, Dave traps Private and the other mermaid penguins'. After the unsuccessful plan, Skipper as the leader of the team fells guilty for his unsuccessful plan.

\subsubsection{Questions}

\section{"Are you my family?"}

The utterance in the second data "are you my family?" is a directive illocutionary act since there is a certain force that the speaker wants to have by uttering the question. The force is called directive of question since the speaker needs information so the hearer needs to provide information. The speaker's utterance is also determined as a direct speech act. This is because the speaker utters his sentences literally and means as what he says. The result that the speaker wants to achieve is to know whether or not the hearer is his family.

Prior to this scene, Private, who is still being an egg accidently rolls fast on the snow, fells into the valley which is full of walrus. Skipper asks why no one tries to save the egg, to which the adults penguin replied that "this happened many times and its nature". Skipper, the leader of the two young penguins, argues and said "I reject nature". Immediately, the two young penguins are gone and risk themselves to save the egg. Eventually, the egg hatch and there is the cute baby Private born.

\subsubsection{Requirements}

"Alright, boys, battle stance."

The third data is a direct speech act. This is because the speaker utters his sentence literally and the meaning is exactly as what he says. The third data is a directive of requirements. Requirements are the expressions where the speaker requires the hearer to do action. In this expression, Skipper as the speaker does not only utter the utterance to the hearer, but also perform the act of commanding.

The content of the utterance is explained here. Skipper is the oldest brother and also the leader of the three penguins, Kowalski, Rico and Private. Dave's henchmen were tried to chase the penguins. During chasing both of them 
fight on boat. Then after the penguins are cornered in an alley by Dave's henchmen and no longer than the north wind agents saved the penguins.

\subsubsection{Permissives}

\section{"Now hit that machine and get your present."}

Bach and Harnish (1979) state that directive for permissive is the kind of directive Illocutionary act is used to express to agree to, allow, authorize, bless, consent to, dismiss, excuse, exempt, forgive, grant, license, pardon, release, and sanction. The forth data is a direct speech act. Because the speaker utters his sentence and means exactly or literally what he says. The utterance, "Now hit that machine and get your present" is also classified as directive of permissive since Skipper, the speaker performed an authorization of excuse to Private

\subsubsection{Advisories}

\section{"I'd recommend firing it now."}

The fifth data is a direct speech act. It is because the speaker utters his sentence literally and the meaning is exactly the same as what he says. The utterance in the fifth data is also a directive for advisories since Kowalski as the speaker is performing an act of advising toward Skipper. The result that the speaker wants to achieve is to tell the hearer to do the action immediately.

The context of the utterance is explained here. The wind blows away the snow, revealing an egg and it rolls down the hill heading to the old ship. The egg rolled passed the baby penguins Skipper, Kowalski, and Rico. With a shout, Skipper goes after the egg, much to Kowalski's and Rico's confusion. The egg stopped at the old ship, immediately with hunger the walrus tried to have the penguin's egg. But, Rico got the egg before them. In order to save the egg, Rico swallows the egg of the penguins and made a confusion to the walrus. At the time, the penguins tried to escape from the walrus by getting to higher place. The penguin gets on the harpoon as the walrus getting hard to capture them. Kowalski recommend firing the harpoon directly; however, Skipper as the hearer waited the moment to fire the harpoon they get on.

\subsection{Indirect of Directive of Illocutionary Acts}

In this analysis, there are five conversations considered as indirect of directive illocutionary act found in the movie Penguin of Madagascar.

\subsubsection{Requestives}

'Skipper wouldn't care! Plan or no, fancy equipment or no. he'd never leave a man behind!"

The data above is a directive for requestives since Private, the speaker does not only say the utterance, and however he hoped that the North Wind agent would help the penguins after they were being released by Private. The utterance 'Skipper wouldn't care! Plan or no, fancy equipment or no. he'd never leave a man behind!" were also indirect speech act. It means the utterance above has another meaning than what is actually said. The literal meaning is that Private stated Skipper would not care about fancy equipment and a proper plan and he never runs away when his soldier are in danger. On the other hand, the indirect meaning is Private is pleading for Classified to help the penguins immediately. In this expression, Private as the speaker does not only utter the utterance, but also performs an act of requesting and he wishes that Classified could change his decision. The result that the speaker wants to achieve is to express 
his desire that he wants Classified to save the penguins.

After being captured, Skipper and the two penguins Kowalski and Rico always look a way to find their little brother. The penguins then agreed to follow the North Wind agent strategy. The penguins, being a diversion and unluckily the North Wind agents, were captured with the penguins too. However, Private could free himself and so the North Wind agent from a death penalty. After being freed, they went to exit the way then they were stopped by Private telling them the penguins are not that way. Unfortunately, after arguing the North Wind agent kept on their assumption.

\subsubsection{Requirements}

\section{"Are you questioning my leadership, Private?"}

The utterance "Are you questioning my leadership, Private?" is a directive for requirements since Skipper as the speaker does not only want to say the utterance, however he also expresses his order to Private. This utterance is also indirect speech act. It can be said that speaker have performed indirect speech act when he utters a sentence that means what he says has more meaning. The first meaning is to ask Private whether he questions the leadership of Skipper. The second meaning is to command Private not to hesitate on Skipper's leadership. The

utterances uttered when the penguins on the way to gold depository at Fort Knox America. In order to celebrate Private birthday, the penguins infiltrate to the most secure place in North America. They are headed to the break room to propose to find cheesy dibbles vending machine as the birthday present for Private.

\subsubsection{Prohibitive}

\section{"What is wrong with you?"}

The data above is a directive of illocutionary act, especially directive for prohibitive. The speaker's utterance "What is wrong with you?" is also indirect speech act. It means the utterance has another meaning that what is actually said. The literal meaning is Dave asked Rico whether it is something wrong with him. However, the indirect meaning is Dave forbids Rico on swallowing his snow globe collection. In this expression, Dave as the speaker does not only utter the utterance to the addressee, but also expresses an act of prohibiting and hope Rico will stop his odd action. Dave, the octopus captures the penguins in his submarine, but the penguins do not seem to understand what is proposed. Moreover, the penguins have no idea who Dave is. Dave explains his depression of being unwanted at every zoo after the existence of the penguins. The human known Dave as Dr. Octavius Brine. However, Dr. Octavius Brine wanted to revenge by his finding Medusa serum which would change the penguins into a scary look animal. Skipper, Kowalski, Rico, and Private are the ones who most wanted penguins because Dave has the worst background among them four. Also the four of the penguins mentioned above have military abilities which make them the most difficult penguins to be capture.

\subsubsection{Permissive}

\section{'I'm sorry boys. But I can't lead you this time."}

The ninth data is a directive of permissive. Since the utterance uttered by Skipper is not only admitting his lack of abilities, but he also expresses his consent to the hearer. The type of the data above is indirect speech act. The speaker has performed indirect speech act 
when he utters a sentence that means what he says has more meaning.

\subsubsection{Advisories}

"But sir, we've got to be five miles up. That pretty much limits our options."

The utterance expressed by Kowalski "But sir, we've got to be five miles up. That pretty much limits our options." is directive illocutionary act, specifically directive for advisories. The outcome that the speaker wants to achieve is to tell Skipper that Kowalski, the speaker does not only say the utterance, but he also wants to warn Skipper about the situation they heading. The utterance is indirect speech act. The direct meaning is that Kowalski wants to tell Skipper that they are in a plane which is pretty high. The indirect meaning is that Kowalski warns Skipper that for the action he would take going to have a high risk. The penguins were in the North Wind headquarters to talk about the mission to capture Dave. Dave hacked into the North Wind system and made a video call that he would like to show the big tank of medusa serum. The medusa serum would change the cute penguins into a scary look and Dave has made a lot of them for the Penguins in the whole world. North Wind agent was getting ready to save the Penguins in the whole zoo. At the time, the four penguins take their part and stole the equipment from North Wind agent. Classified notice the attitude by the penguins, there he gave a stun shot and shipped them in a package to Madagascar.

\section{Conclusion}

In order to conclude the analysis based on the analysis on previous chapter, there are two points which can be drawn as the conclusion of the study. Directive is one of types of illocutionary acts. The illocutionary point

of these acts attempted by the speaker is to get the hearer to do something, expressed by the propositional content. In this study five out of six types of direct directive illocutionary were found in the movie namely requestives, question, requirements, permissive, and advisories. On the other hand, several indirect directive illocutionary acts were found, except indirect question. In conclusion, five types of each direct and indirect directive illocutionary act were found in the movie. The content of an illocutionary act "what is said" is not always determined by what is meant by the sentence being uttered. There we perform different speech act directly or indirectly. The direct speech is the simplest case of meaning in which the speaker utters his sentences and means exactly or literally what he says. On the other hand, in indirect speech acts the speaker communicates to the hearer more than what actually the speaker says. Based on the data, they are classified as the types of directive of illocutionary act such as; requestive, question, requirements, permissive, prohibitive and advisories.

The second aims of this study is that to gain the accurate interpretation of the meaning behind the utterance. The context of situation is presented since an utterance uttered by the speaker can have more than one meaning depending on the context. It is important both speaker and hearer in understanding the utterance of the speech act based on several factors found in the analysis of the data that influence the participants. The context of situation factors are setting and scene, participants, ends, act sequence, and key.

\section{Refrences}


Austin, J.L 1970. How To Do Things

With Words. New York: Oxford University Press

Bach, K. and Harnish, R. 1979.

Linguistic Communication and Speech Acts.Cambridge: The MIT Press

Barsam, R.M 2009. Looking at Movies an Introduction to Film. W.W. Norton \& Company,Inc, 500 fifth Avenue, New York.

DreamWorks, A. (2014). Penguin of Madagascar Movie Synopsis (Internet). IMDb, USA. Available from:

http:/www.imdb.com/title/tt19116 58/plotsummary?ref_=ttpl_ql_3\#s ynopsis (Accessed November 11, 2017)

Hymes, Dell. 1972. Toward Ethnography of Comminication: the Analysis of Communication Events.InGiglioli 1972: 22-24

Searle, J.R. (1970).Expression and Meaning: Studies in the Theory of speech Acts Cambridge:

Cambridge University Press.

http://www.yify.is/movie/view/penguinsof-madagascar/2014 